\title{
EVALUATING ELECTION MANAGEMENT IN SOUTH AFRICA'S 2009 ELECTIONS
}

\author{
Kealeboga J Maphunye \\ Dr Kealeboga J Maphunye is Manager: Research and Knowledge Management, \\ Electoral Commission of South Africa ${ }^{1}$ \\ e-mail: maphunyek@elections.org.za; khoisan123@yahoo.co.uk
}

\begin{abstract}
This article examines election management and the role of South Africa's election management body (EMB) in the context of the country's 2009 elections. It outlines and analyses the dynamics and challenges faced by South Africa's Electoral Commission in managing the country's fourth democratic election, argues the case for election management and emphasises that election management can help in the promotion of electoral democracy. Specifically, the paper analyses the financial costs and other challenges experienced by the Electoral Commission during the 2009 elections, including those related to overseas voters, the use of technology to enhance election management, and the importance of EMBs in the planning and management of elections internationally. The paper concludes with an assessment of the relevance of election management in the promotion of electoral democracy and proposals on how effective election management may contribute to the success of meaningful and sustainable elections to enhance South Africa's democracy.
\end{abstract}

\section{INTRODUCTION}

For many countries which hold regular free and fair democratic elections, election management presents as many complexities as it does opportunities for understanding the running of elections. This is especially the case in African countries that are deemed to possess '... most of the important ingredients of liberal democracy, including the existence of an Independent Electoral Commission' (Sebudubudu \& Botlhomilwe 2010, p 65). On the one hand, the opportunities usually stem from a range of interactions between and among the different

1 Dr Maphunye writes in his personal capacity and the views expressed in this paper are the author's personal opinions and do not, in any way, represent those of the Electoral Commission of South Africa. 
stakeholders, including the voters, candidates, political parties and numerous other actors, as well as the institution charged with managing the elections.

On the other hand, most of the complexities relate to the fact that running an election is an elaborate process that requires various skills, including knowledge and expertise in implementing relevant legal and regulatory frameworks; public sector administration and management skills; effective organisational and events management measures; the ability to respond to the needs of the electorate in various ways such as providing them with the necessary information before, during and after an election and the ability to make the relevant arrangements. Such arrangements include procuring goods and services to ensure that an election takes place not only according to legal requirements but also according to appropriate logistical best practice.

Observers state that 'As a new field of study and practice, election management has emerged from the areas of democracy-building and democratic consolidation' (UNDP 2000, p 15) and usually involves issues related to the establishment of a body or institution that is charged with the responsibility for managing elections in a country.

This article will highlight the significance of election management logistics, especially the administrative and operational processes without which elections cannot be run or succeed. Such processes and systems in an elections management body (EMB) include its strategic and operational functions, which will be examined within the context of South Africa's recent (2009) national and provincial elections.

Election management, it will be argued, is a process whose complexities should not be overlooked or ignored as it plays a crucial role in ensuring fairness, freeness and credibility, which contributes to processes of democracy-building and consolidation.

The financial costs and challenges of South Africa's elections, especially the need to cater for overseas voters, and the importance of EMBs in the planning and management of elections internationally will be discussed. Specifically, the article will attempt to unpack the management challenges, opportunities and dynamics of election management, including administrative tasks, human resources, regulatory framework and legislation and to discuss each item in terms of South Africa's 2009 elections.

Using these elections as a point of reference the article will conclude with an analysis of the extent to which election management systems and logistical arrangements can contribute to the credibility of an EMB, to the legitimacy of the election process, and to impartial international election observers ultimately declaring a country's election free and fair. The conclusion will also assess the relevance of election management to the promotion of electoral democracy, 
and propose ways in which it can contribute to sustainable elections, thereby enhancing South Africa's democracy.

\section{THE CONTEXT OF POST-1994 ELECTION MANAGEMENT IN SOUTH AFRICA}

Despite the fact that much still needs to be done to improve the running of elections in South Africa, the Electoral Commission (IEC) of South Africa (formerly the Independent Electoral Commission) ${ }^{2}$ has been congratulated by political parties '... for facilitating successful elections over the years' (IEC 2007, p 39).

An overview of elections held between 1994 and 2005 suggests that South Africa has been steadily improving in the running of local, provincial and national elections, if the general acceptance of election results and the peaceful resolution of disputes may be used as a yardstick. As observers note, 'The IEC has been effective in ensuring the continuous preparation for and management of free, credible elections - partly through the facilitation of continuous cooperation with political parties' (Booysen \& Masterson 2009, p 396). While this article will not delve into election management issues for all the elections it is necessary to assess briefly the way they were managed.

The 1994 poll presented many challenges, not only for electoral officials but for voters and political parties. There was no comprehensive national voters' roll, other logistical systems or properly trained personnel to run the elections. Thus, although South Africa was widely praised for the elections, which ushered in a new democracy, from an election management point of view many of the activities, decisions and plans were either ad hoc or relied largely on trial and error. Moreover, the fact that virtually all international media organisations focused on South Africa during the elections meant that the pre-election tensions and violence, the many teething problems voters and parties experienced on voting day ( 27 April 1994) and post-election anxieties and uncertainties clearly indicated that the country still had to improve its election management processes and systems.

Some of the problems stemmed from the fact that the 1994 electoral team had only a few months 'to prepare and conduct the most crucial elections' (IEC 2007, p 4), coupled with the fact that 'When [these] elections were held ..., 22 million people were eligible to vote, 17 million of whom had never voted before' (Deegan 1999, p 3). Election management has continued to improve:

2 This abbreviation of the Independent Electoral Commission that was established under the provisions of the 1993 Constitution sometimes appears confusing as current legislation only refers to an 'Electoral Commission'. 
from the 1994 challenge of daunting organisational tasks (eased through the euphoria of the time), and the 1999 challenges to its relatively autonomous status. In the subsequent two elections the performance of electoral management tasks became institutionalised and the IEC adequately resourced and fully accepted its role.

Booysen \& Masterson 2009, pp 396-397

Yet some challenges to effective election management continue to pose problems for the IEC. For instance, as Ajulu (2010, p 4) notes, the 1999 elections 'were held ransom by the voter registration controversy, a contestation over which form of identification would be used for purposes of voter registration and, ultimately, for voting'. Nevertheless, this matter was eventually settled by the judicial system in favour of the use of barcoded identity documents for registration and voting. Thus, the 1999 elections 'took place in an almost festive atmosphere. Missing from the electoral process this time around was the violence that almost derailed the 1994 election' (Ajulu 2010, p 4).

This paved the way for further improvements in election management as well as infrastructural arrangements by the Electoral Commission which, between 2000 and 2006, 'utilised the full technology complement at its disposal to assist participants in the electoral process' (Tlakula 2006, p 4). In many ways the introduction of information technology (IT) in election management steadily improved efficiency and effectiveness as well as the implementation of election schedules and timelines. As the IEC acknowledges, 'Much of the work of information technology professionals takes place behind the scenes. However, this work impacts on a spectrum of activities, from delimitation of voting districts and candidate nominations to the results system' (Tlakula 2006, p 4).

According to Ajulu (2010, p 5), 'The 2004 elections were yet another demonstration that regular democratic elections had become institutionalised in South Africa's political landscape', but clearly this could not have been achieved without effective election management, which paved the way for even more successes in the future. For instance, as Booysen \& Masterson (2009, p 406) state, 'The 2004 and 2009 voter registration processes remained largely similar to that of 1999, although voters who had previously registered were not required to reregister.'

Essentially, the overall picture of the management of elections since 1994 has been positive and is, arguably, even better now than it was before 1994 when elections were run by the apartheid era Department of Home Affairs, whose credentials were questionable, given that issues of impartiality, transparency and free and fair elections would not be guaranteed under a government agency. Moreover, elections prior to 1994 excluded the majority of the country's citizens. 
It is in this context that South Africa's post-1994 challenges or teething problems in election management should be understood.

\section{THE SIGNIFICANCE OF ELECTION MANAGEMENT}

The administration or running of an election is very often a matter that is overlooked, misunderstood or merely ignored by political analysts, opinion poll commentators, political parties and the media. The reasons for this are not immediately apparent, but anecdotal evidence in South Africa suggests that this complex administrative and logistical exercise is often erroneously dismissed as unimportant. Yet it involves taking decisions about critical matters such as how many ballot papers to print and what kind of ballot boxes to use, the provision of voting stations and the demarcation of voting district boundaries.

Though apparently mundane, items such as marking ink, security tape and seals for ballot boxes and other containers, secure and adequate warehouses and other security materials are critical to the credibility of an electoral process. Beyond these logistical arrangements, in 2009

... the Commission introduced a few innovations. One of these [was] the scanning of results slips. This means that, in addition to the posting of the results slips at the voting station and the capturing of the results on the results system, a physical image of each result slip [was] ... scanned and recorded.

IEC 2009a, p 7

Judith February (2010, p 48) argues that 'Elections, in order to be truly free and fair, must be competitive, and for the [electoral] system to be seen as legitimate they must reoccur with reasonable regularity.' Such 'reasonable regularity' suggests that the challenge is not only to provide logistics and personnel but also to devise effective and sustainable strategies to ensure that as many prospective voters as possible are able to exercise their right to vote in terms of constitutional or legislative provisions whenever an election or by-election is held.

Similarly, the idea of ensuring a free and fair election process is quite significant, seen from the perspective of the logistical process of election management. In fact, in an African context, especially in view of what happened in Lesotho in 1998, Madagascar in 2001, Kenya in 2007 and Zimbabwe in 2008 (Sebudubudu \& Botlhomilwe 2010, p 67), the competitiveness of an electoral process is prone to generate violent or emotion-charged skirmishes. Such incidents may emanate from poor election management or fraudulent behaviour or disputes over results, especially in a situation in which the electorate or members of the 
public suspect that logistical arrangements and election management are either disorganised or have been tampered with (pertinent examples being the above case studies). Ultimately it is the responsibility of election managers, organisers and the relevant EMB to put in place effective and efficient mechanisms to prevent or avoid the recurrence of any practices that might affect or undermine a country's electoral system.

To use a sports metaphor, an EMB is analogous to a soccer referee who protects both players and teams against bias, fraud or any illegal activities likely to compromise the game. Perhaps, as Sebudubudu \& Botlhomilwe (2010, p 65) maintain, 'It is indeed inconceivable that democracy can exist in the absence of elections. As such, the way elections are conducted has a bearing on democracy.' Similarly, it may be argued that there can never be free, fair and credible elections without effective and efficient election management.

\section{CHALLENGES AND OPPORTUNITIES OF THE 2009 ELECTIONS}

Management of elections covers numerous issues in multiple phases. Planning for such activities is just as vital as the actual voting process itself, as Kimmie, Greben \& Booysen (2010, p 120) note: 'It is also commonplace that planning and preparations by the relevant elections management body - in the case of South Africa, the IEC - are imperative to the credibility of the elections.' There are three phases in the IEC's processes and electoral activities: pre-election, election day and post-election.

\section{The pre-election phase}

Generally no hurdles or confusion were experienced in relation to the 2009 elections. This is largely because South Africa now has an established legislative regime that governs every aspect of electoral activities and specifies the responsibilities of each stakeholder and the timeframe within which the activities are undertaken. The legislative regime includes:

- Constitution of the Republic of South Africa (Act 108 of 1996)

- Electoral Commission Act (Act 51 of 1996) and regulations

- Electoral Act (Act 73 of 1998) and regulations

- Public Finance Management Act (Act 1 of 1999)

- Local Government: Municipal Structures Act (Act 117 of 1998)

- Local Government: Municipal Demarcation Act (Act 27 of 1998)

- Local Government: Municipal Electoral Act (Act 27 of 2000)

- Municipal Electoral Regulations (R 848, dated 23 August 2005) 
- Public Funding of Represented Political Parties Act (Act 103 of 1997)

- Public Funding of Represented Political Parties Regulations (R117, dated 20 November 1998).

Among the many examples of administrative functions and duties that electoral officials and staff in all provinces had to undertake in the 2009 elections were those encompassing planning and implementing systems and processes, events management and catering, coordinating and monitoring equipment and supplies and making transport and communication arrangements for electoral staff. They also included renting or procuring vehicles to transport materials and supplies, voting station furniture, computer equipment, machines, tools, and so on, as well as financial arrangements for marketing and publicising election campaigns.

Beyond the routine activities securing adequate financial allocations from Parliament for electoral events, including by-elections, remains a serious challenge for the IEC. Sometimes the commission runs into bureaucratic hurdles surrounding the use of such funds, which may both delay the implementation of expenditure and result in the inability to spend the amount required and allocated. More serious, though, is the question of the funding of political parties, which repeatedly stirs up complaints, often from smaller political parties that receive either minimal or no funding, which limits their ability to mount effective campaigns. Indeed, an IEC conference in 2007 noted that 'The formula used in the funding of political parties was identified as allegedly "limiting the capacity of smaller parties to mobilise membership and sustain themselves"' (IEC 2007, p 5).

Similarly, the registration process, and voter education campaigns often present challenges for parties, voters and the IEC alike, as each must play its part. The challenge for the parties is to ensure that their supporters are not only registered but will go to the voting stations on election day. The regular meetings, public consultations and feedback and elaborate preparations by the parties for the elections also help to lay the foundation for credible elections, something that might be overlooked or ignored.

Another challenge for the parties that is frequently overlooked is that they must submit themselves to, and ensure that their members observe, the binding code of conduct which all registered political parties must sign in line with the provisions of Schedule 2 (Section 99) of the Electoral Act.

For voters the challenge is usually how to obtain updated information about the impending election, and this is where the IEC as well as the mass media may be helpful. In particular, a significant number of potential voters reported positively about the information they obtained from the print and electronic 
media (Human Sciences Research Council - HSRC 2009, pp 50-54). Equally, as Booysen \& Masterson (2009, p 414) report, 'In 2009 for the first time political parties were afforded a limited amount of free electronic (television and radio) party advertisement broadcasting. It was, however, overwhelmingly only the well-resourced parties that could make use of this opportunity.'

For the IEC, which, in 2009, mounted countrywide registration campaigns, the key challenges included the need to increase voter registration figures, ensure the visibility of its posters and billboards, and generally to guarantee a climate conducive to the holding of free and fair elections. As always, it also faced the logistical task of setting up systems and infrastructure for voting stations. Such tasks included provisions for staff or personnel, including transportation for them and their materials and equipment, food, accommodation, uniforms or identification tags, as well as the relevant time management and precision planning that underpin these processes.

The timing of the announcement of the election date presented the IEC with a logistical challenge. The date (22 April) was announced on 19 March 2009 by then president Kgalema Motlanthe. This gave the IEC barely a month to prepare for the event, which was too constraining in terms of the many arrangements that had to be put in place. The announcement of national election dates in South Africa is often shrouded in secrecy and poses a logistical nightmare for the EMB. South Africa could learn a lesson from a country like Botswana, which announced the date for its 2009 elections months before the actual event, allowing the electoral commission in that country ample time to prepare.

Most challenging, however, was making arrangements for overseas-based South African citizens to cast their votes. The following reasons are set out as requirements for a special vote in terms of chapter $3 \mathrm{~s} 33$ of the Electoral Act:

a) physical infirmity or disability or pregnancy;

b) absence from the Republic on government service or membership of the household of the person who is absent;

c) absence from a voting district while serving as an officer in the election concerned;

d) being on duty as a member of the security services in connection with the election;

e) temporary absence from the Republic for purposes of a holiday, a business trip, attendance of a tertiary institution or an educational visit or participation in an international sporting event.

These provisions - especially clauses (b), (d) and (e) - were challenged by opposition parties, which argued that the Act discriminated against South Africans living 
abroad. Consequently, the Constitutional Court declared the relevant section of the Act unconstitutional, thus allowing all people living abroad who could prove their South African citizenship the right to vote in the 2009 elections. In addition to producing their proof of registration and their green barcoded identity document (ID), such citizens had to produce valid South African passports before they were allowed to vote at the country's diplomatic missions abroad (IEC 2009c).

The ruling, which, in terms of constitutional democracy, was nationally and internationally applauded, created logistical nightmares and management dilemmas for the IEC. To start with, the commission's plans all focused on the millions of voters who would be casting their ballots in the country; it had not anticipated additional overseas voters who suddenly had to be added to the voters' roll. Subsequently, this meant that the commission had to prepare at short notice and to make contingency plans to accommodate a large number of overseas voters as well as make arrangements for the safe return of ballot boxes once the containers were properly sealed for shipping back to South Africa.

Other challenges were that the numbers of voters involved could not be determined accurately. Moreover, they were not covered by the commission's national communication and voter education campaigns and many apparently only possessed South African passports and not the requisite ID book or a legally recognised temporary identification certificate, as the Electoral Act 1998 stipulates.

In addition, all South African voters in the 2009 elections were categorised according to voting districts (VDs), whereas this was not the case for voters in London, New York or any other overseas capital where South Africans were residing at the time of the elections. With 7472 registered voters the UK had by far the largest number, followed by Australia (1235) (IEC 2009c). Furthermore, the Electoral Act clearly stipulated that those voters who were out of their province on election day could only cast a national ballot. For overseas voters this posed a challenge, as the Constitutional Court's ruling did not give a directive on this matter. Moreover, those who lived far from the capital city of their host country faced additional logistical and other challenges as they had to cover the costs of travelling to the capital to cast their votes.

The implications of all the logistical problems in terms of the IEC's own preparations, costing, counting and so on initially posed several challenges, but these were not insurmountable and were eventually resolved. For instance, the commission relied largely on the country's existing diplomatic missions and embassies for most of the logistical arrangements, security and other necessary preparations. The overseas votes were sealed and sent back to South Africa to be counted by experienced officials and were later included in the ballots from domestic voters. 
In Africa absentee ballots, that is, 'vote[s] cast by someone who is unable or unwilling to attend the official polling station' (en.wikipedia.org) continue to pose challenges for proponents of extending franchise rights to all citizens, using multi-media platforms and mechanisms such as postal, proxy and Internet voting. Arguably, South Africa may be ahead of many African countries in terms of extending overseas voting to all its citizens abroad. However, unlike countries such as the United States, France, the United Kingdom, Switzerland and Estonia, where the Internet has been used (wikipedia.org), this is not yet the case in South Africa owing to widespread concerns about possible threats to the secrecy of the vote. Moreover, high illiteracy rates as well as the inability of many poor citizens to gain access to computers and the Internet mean that it might be too early to expect South Africa to opt for electronic voting in its next (2011 and 2014) elections. This is despite the South African government's apparent excitement over the possibility of introducing electronic voting for these elections, which was alluded to by then president Kgalema Motlanthe during his acknowledgement of the April 2009 election results in Pretoria (22 April 2009).

If recent local media reports are anything to go by, government may be considering merging the national, provincial and local elections into a single election in 2014. Since this might create even bigger logistical challenges for the IEC it would probably not be worthwhile to complicate matters further by also introducing electronic voting without first examining its advantages and disadvantages in the South African context.

\section{The election phase (election day)}

On 22 April 2009, 19726 voting stations across the country opened to voters (IEC 2009h, p 6). Among the voters were 743609 people who had applied for special votes on the basis of physical infirmity, absence from the country on government service or absence from the voting district in which they were registered while serving as election officials, being on duty as a member of the security services in connection with the election or being out of the country (IEC 2009h, p 92). The IEC reported (2009h, p 93) that the election largely went smoothly and further that,

Between 7:00 and 21:00 on 22 April 2009 registered voters cast their national and provincial ballots at the voting stations at which they were registered to vote... A new operational function was introduced in the 2009 elections, namely, scanning the bar-code of the voter's identity documents prior to voting. This allowed voting officials to more efficiently locate the names of voters on the voters' roll. Also, 
it allowed the Commission to analyse the demography of the voters - also a first for the Commission.

The HSRC's exit poll showed that

The IEC officials were rated highly by over $80 \%$ [of the respondents] on helpfulness, friendliness, cooperativeness, professionalism [and] extent of knowledge about elections, honesty, and level of interest in their jobs and their considerate nature. The officials were however rated low on the aspect of impartiality $(77 \%)$, when compared to other aspects.

HSRC 2009, p 55

While this figure is high, it is possible that this observation might be linked to the fact that concerns were previously raised about the employment as election officials of teachers, the majority of whom belong to the SA Democratic Teachers Union, an affiliate of the Congress of SA Trade Unions, which has previously called upon all its affiliates to vote for the governing African National Congress (IEC 2007, p 41).

Observers frequently not only emphasise the need for an EMB to be independent (eg, from the ruling or governing party / parties), impartial, transparent and accountable to the electorate and general public but also that such bodies must display 'professionalism and better service delivery' (Sebudubudu \& Botlhomilwe 2010, p 71; see also Dundas 1993 and Rukambe 2006, cited in Sebudubudu \& Botlhomilwe, p 70). Emphasis on professionalism inevitably raises the sensitive issue of the extent to which EMBs must avoid political appointees (or individuals with overt or covert links to political parties) or at least ensure that they do not appoint personnel or staff who are aligned to a specific party or organisation, which could undermine such professionalism or compromise the EMB's impartiality. In South Africa the IEC has been rigorous about not appointing staff with a high political profile, despite the controversy surrounding the use of teachers as officials in previous elections.

Other challenges of the 2009 elections may be covered under the subject of human resources, namely wages or salaries of the electoral personnel, the provision of technical equipment and relevant materials and the training and capacity development of administrative and support staff, many of which straddled all the phases of the elections. While human resources and good election administration are critical to the running of elections, it is argued that

Being a successful election administrator is more than effective organisation of staff and resources. The election administrators 
must also manage the (for a lack of a better term) public process of the election. That is, public relations and the press, political party relations, and relationships with non-governmental organisations (NGO).

Baxter 1994, p 7 (emphasis in the original)

A training manual for the electoral staff who conducted the 2009 elections underscores the crucial role of election officials in particular and human resources in general in election management, outlining their responsibilities as follows:

As an Election Officer at a voting station, you are charged with very important responsibilities. The way in which you carry out your duties will influence the confidence of voters, candidates and political parties in the integrity of the election process. Each Election Officer has a role to play in ensuring a free and fair process within the boundaries of his or her voting station and therefore in protecting the right of every registered South African citizen to participate in the election.

IEC 2009b, p 5

Each of the above logistics offered opportunities in the sense that the plans, projects and programmes made by the Electoral Commission for the 2009 elections were reviewed and assessed with a view to finding out how far they could help in the preparation of these elections. The challenges were to secure the relevant budgets and to reach remote voting stations or those in areas with minimal infrastructure in terms of roads and electricity.

Another challenge frequently experienced by electoral staff related to the use of technology to enhance the electoral events. For instance, the handheld barcode scanners, popularly known as 'Zip-Zips', which had been used in previous elections, were loaded with the names of 23 million voters and these gadgets significantly improved the commission's state of readiness for the elections (IEC 2009e). The way this equipment was used was that before registration or voting

... the registration official would take the map for the voting district and, using the bar-code on that map, register the Zip-Zip machine to a particular voting district. All registrations of voters [or actual votes] scanned during the day would then be linked to the bar-code of that voting district. 
The scanners are innovative, user-friendly machines which help to speed up the registration and voting processes. However, one of the challenges experienced at some voting stations emanated from the malfunctioning of the equipment, either because the battery could not be charged the night before or because of some other technical fault which could only be fixed with the intervention of technicians from distant voting districts or the national office of the Electoral Commission.

Another problem faced by electoral officers related to when to rest, to take comfort breaks or to break for meals. In some voting stations officials could not afford such breaks owing to the long queues. In addition, many of the contract or temporary staff, including the 'volunteers' who were hired by the Electoral Commission to assist at voting stations countrywide, had to deal with the challenge of extended time but without an increase in their wages, factors that were frequently reported in the national media.

On the whole, as recorded in the report of the HSRC's exit poll, in local and international media reports and in the IEC's account of voting day, the election was properly run. Most voting stations opened and closed on time, although there were a few where a lack of electricity caused problems, in which case presiding officers followed legal guidelines about closing the stations earlier. Almost all voting stations had sufficient voting materials but in some cases voters chose to vote at stations where there were fewer voters, but at which they were not registered. This was an example of the so-called 'vote anywhere' syndrome provided for under s 24 of the Electoral Act. Political parties probably exploited the situation by 'bussing in' voters from voting stations with many voters or longer queues to those with fewer voters and shorter queues. The end result of this move was the following:

- Officials could not always locate voters on the voters' roll, which undermined efficiency, as relevant forms had to be completed by the voters and authorised by the presiding officers before voters could cast their ballots.

- Some officials suffered from fatigue or burnout as they were inundated with seemingly endless queues. Consequently, breaking for lunch, dinner or rest was out of the question. This resulted in low morale and motivation as the officials faced a barrage of media questions or complaints from impatient voters, many of whom had spent hours in the queue.

- As queues lengthened, tempers and emotions rose as voters were angered by the length of time it took some of them to vote. It might not be possible to determine the number of voters who left, vowing not to vote, but if they were discouraged by the long queues this 
might be an example of logistical (mal)functions impeding electoral democracy.

One of the reasons for the lengthy queues was Zip-Zip machines breaking down or becoming inoperable due to, among other factors, batteries going flat because they had not been charged properly. Voters flocking to voting stations other than their own added to the problems. In most cases, voting stations only had sufficient ballots for the number of voters who were originally assigned to them.

In addition to the electronic barcode scanners the Electoral Commission relied on multi-media platforms to manage the elections and urged the voters to log onto its website (www.elections.org.za) and to visit its call centre (0800 11 8000) or send a short text message (SMS) to verify their registration details. The use of billboards, electronic and print media advertisements, and a television drama on elections on one South African Broadcasting Corporation channel also went a long way in sensitising the public about the 2009 elections.

\section{The post-election phase}

This important period, which covers the seemingly minute issues such as the removal of IEC and party posters after an election, in terms of legal requirements, is often taken for granted by parties, observers and voters. The post-election phase also deals with any disputes arising from an election and seeks to ensure that these are resolved in terms of legislation, that clear records of the election are kept and sent to the IEC's national office and that all reports from local and international observers are received so that they may be analysed when the commission assesses the election. To the extent that the 2009 elections generally followed this pattern, it may be said that they were a success, especially since very few incidents of election-related violence were reported.

A few other factors must be considered once an election has been held. Firstly, it is usually immediately after an election that the public is given full information about the preparations and by then interest has largely waned. Before then, focus on elections management usually takes a back seat owing to the campaigning, pre-election tensions, scandals, propaganda, and so on that usually make media headlines. Secondly, in most countries, unless controversies arise the public may never know about the elaborate and meticulous planning and management that accompany an electoral event. While some countries regularly compile comprehensive reports on their electoral events, the public rarely sees these reports. Thirdly, based on an elections management body's experience and record of conducting elections it will always be expected to excel, especially once the electorate's confidence in democratic participation grows or matures. 
Typically, the management of an election goes through what may be called an election cycle, graphically depicted in Figure 1.

\section{Figure 1}

\section{Processes and preparations surrounding election day}

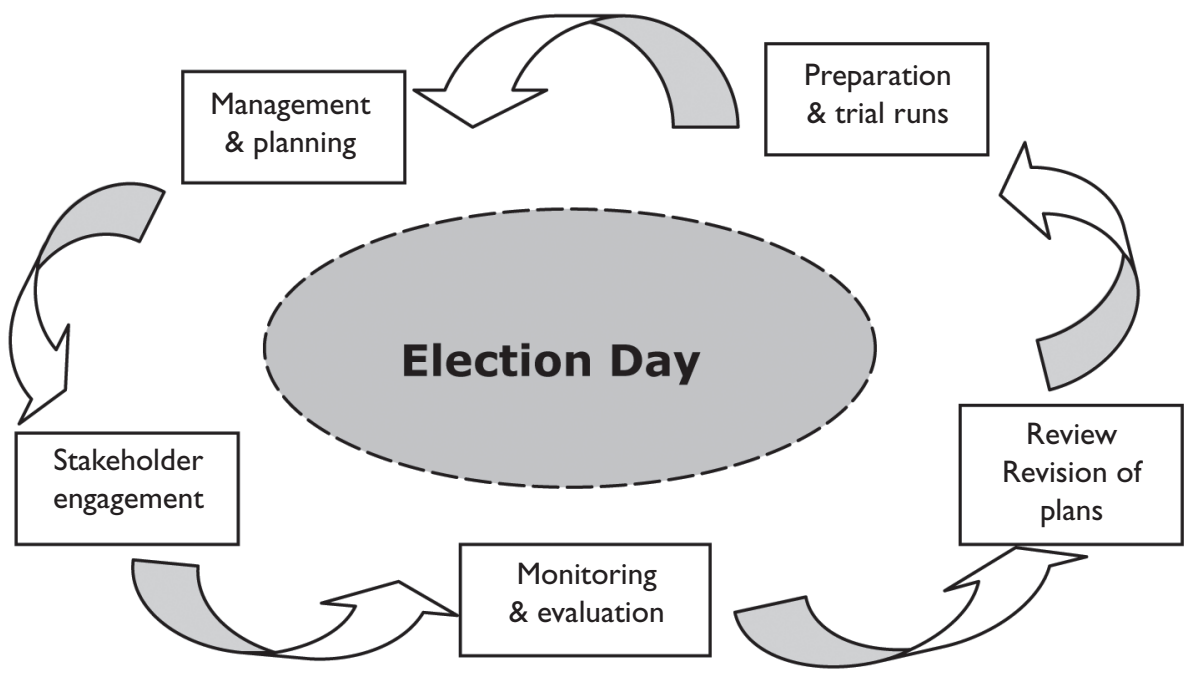

Source: author's own analysis

Logistical arrangements for South Africa's 2009 elections involved the production and procurement of:

- 394400 staff identification stickers

- 55000000 ballot papers

- 97002 ballot boxes

- 92700 voting compartments

- 46700 stationery packs (49 tons of stationery)

- 40000 banners

- 19726 segments of voters' roll, amounting to 1.55-million pages (some 7.5 tons of paper)(IEC 2009a, p 53).

In addition to the above, by September 2008 the electoral commission had produced '... 20 million voter registration forms, 300000 street pole posters, 44000 stationery packs (which amount to 44 tons of stationery) and 40000 banners...' and 
was to procure more electoral material closer to the actual elections (Tlakula 2008). This also involved enhancing the IT infrastructure 'to ensure the smooth running of the registration, voting and results processes' including the buying of 30000 new Zip-Zip scanner units with state of the art technology that was expected to boost the electoral process significantly (Electoral Commission 2009g).

Despite these massive volumes of electoral materials nothing would have delivered the goods more effectively and efficiently than careful and meticulous planning for each of the 19726 voting stations (IEC 2009a), but in many instances the costs involved also constituted a crucial part of the equation, as discussed below.

Altogether 'approximately 460 tons of paper was used to print 55543000 ballot papers ... in full colour, containing the name, emblem and abbreviated name of the party, as well as a photograph of the party leader'(Electoral Commission 2009h, p 73). According to Booysen \& Masterson (2009, p 408):

[the] number of registered political parties in South Africa fluctuates, and the number of registered parties is also far larger than the number of contesting and represented parties ... The following numbers of political parties contested for representation in the nine provincial legislatures in April 2009: 17 in Eastern Cape, 14 in the Free State, 20 in Gauteng, 17 in KwaZulu-Natal, 18 in Mpumalanga, 16 in North West, 13 in Northern cape, and 22 in the Western Cape.

For the electoral staff in particular the challenge is to ensure that an updated list of these parties is maintained, as well as to ensure that they participate in the party liaison committees in which critical issues pertaining to each election are discussed with the IEC.

Not surprisingly, 'The unexpectedly large increase of registered voters during the second registration weekend [7-8 February 2009] presented challenges for procurement of electoral materials, which [was] planned and quantified many months ahead of the elections' (IEC 2009h, p 73). The storage and distribution of bulky election materials might have presented challenges to the IEC during the 2009 elections but the commission relied on its warehouses in each province as well as at the national office for storage and distribution. Thus, storage and distribution were not very serious challenges to the commission during the 2009 elections.

The management of an election essentially rests on the shoulders of the thousands of men and women who must ultimately ensure that strategic decisions are implemented on the ground and that ballot papers are collected and delivered at voting stations on time, ballot boxes are available, ink, stationery and signage 
are ready and provided to all voting stations, and so on. This underscores the importance of human resources in election management. Another vital matter is to ensure that the wages or salaries of local staff and volunteers, who are often hired during elections, are paid in good time, that their conditions of service are clearly explained and that transport, office equipment, uniforms, and so on, are supplied and ready for use. This reduces unnecessary tensions or possible labour related grievances and helps to create an environment that is conducive to delivering a successful election.

\section{THE COSTS OF THE 2009 ELECTIONS}

The relevant legislation states that '[t]he Electoral Commission's financial statements and accounts are submitted to Parliament by way of a statutory prescribed annual report' (IEC 1999, p 85). Elections are expensive and the role of money is important, not only to political campaigns but also to the running of the elections themselves, as Green (2006, p 58) explains:

Almost everyone believes that money matters in winning elections. After all, money pays for the many ways that citizens are contacted and persuaded to vote for a candidate - including paying salaries of the political professionals who increasingly direct such efforts.

According to Oyugi (2003, p 2), 'an election is a very expensive undertaking because it is necessary to set up polling stations across the country and ensure they are of a standard that facilitates free and fair elections'. For South Africa's 2009 elections these costs, especially those relating to the procurement of resources such as ballot papers, ballot boxes, electronic equipment, stationery and so on, had a tremendous influence on the management of the elections.

In addition, one has to factor into the costs the fact that the country was experiencing an economic recession in line with global trends. Other cost factors that often threatened to undermine the management of the election were the everincreasing prices charged by unscrupulous service providers who regard the IEC and other public sector institutions as 'cash cows' to be milked dry through the escalation of prices for their goods and services. In some areas the normal rental prices for tents or chairs to be used at voting stations would be doubled simply on the basis that some service providers viewed any election as an opportunity to 'make a killing'. Needless to add, the process of either persuading such service providers to revise their exorbitant prices or to identify alternative providers tends to threaten longstanding deadlines. In this regard, the commission probably shares many experiences with government departments and many public sector entities, 
which are increasingly targeted by fraudsters and unscrupulous individuals eager to 'make a quick buck'.

Issues of resources and the costs of running elections are a continental phenomenon. As Oyugi (2003, p 4) explains: 'There is a general agreement among students of electoral politics in Africa, that elections have become very costly not only for the governments that have to manage them, but also to the political parties and individual candidates.' While Oyugi refers to parties, candidates and governments, the missing link in South Africa's case is the EMB, namely the Electoral Commission. For the commission relies on the usual annual budget allocation from Parliament, whose estimates may not always accommodate all the vicissitudes of running elections including, among others, the need for innovation and flexibility to accommodate spiralling inflation and election timeframes and deadlines.

The emphasis on costs is intended to indicate that in preparing for elections an EMB must always consider the perennial increases in the costs of resources or materials, including inflation and other economic dynamics. Notably, observers argue that it cannot be assumed that '...the most straightforward and least expensive [electoral] system is always the best choice', (IDEA 2005, p 153). Even apparently simple matters such as human resources pose challenges for any electoral system. Thus, as IDEA (2005, p 153) further explains, 'In any country, the logistics capacity and the availability of skilled human resources may constrain the available options for electoral system choice, as may the amount of money available.' In South Africa, while it is unusual for the IEC to release actual figures for each election, it is increasingly becoming clear that elections generally have huge financial implications.

\section{CONCLUSION}

A case can be made for accurate, efficient and effective election management as an important ingredient in running credible, free and fair elections. South Africa's 2009 national and provincial elections were managed in accordance with relevant electoral legislative and policy frameworks which were implemented by the Electoral Commission as one of the constitutional bodies charged with running elections in the country. Election management constitutes the crux of electoral democracy as it helps to ensure that the elections are run according to international standards or best practices, using reputable administration and management techniques.

It has been argued in this article that effective and efficient management of elections essentially determines the outcomes and outputs of an election and is therefore of strategic importance to the promotion of electoral democracy in 
South Africa. This author believes that if anything were to go wrong during an election all eyes would focus on the election management body and its systems, processes, practices or procedures. Such a focus might also include questioning its credibility, impartiality, competence and independence. However, it is argued that proper management systems and logistical arrangements can contribute to the credibility of an EMB, thereby enhancing the legitimacy of the election process and the democratic process generally. The assumption is that such an EMB would have adopted or put in place rigorous measures to ensure that personnel with ethical and non-party-political backgrounds, appropriate skills and competencies are appointed as election officials.

Looking at the challenges of the 2009 elections there are two proposals to be made about how election management can help to contribute to the success of meaningful and sustainable elections and thus enhance South Africa's democracy. Firstly, for the country to ensure the sustainability of successful elections it needs to invest in the continuous and systematic training of elections management officials who are permanently employed to conduct elections. Such training must cover all electoral matters, especially ethical, professional, managerial and logistical or operational aspects of running elections.

The training must be conducted by the Electoral Commission but in collaboration with relevant tertiary and research institutions, experienced, reputable and credible EMBs, and international and local civil society or nongovernmental organisations such as the Electoral Institute for the Sustainability of Democracy in Africa (EISA), the Institute for Democracy in South Africa (IDASA) and the International Institute for Democracy and Electoral Assistance (IDEA). Enhancing the EMB's ability to fulfil its mandate to deliver successful, credible and transparent elections based on the rule of law should be the main objective of such training. Secondly, it is proposed that Parliament, while retaining its oversight powers over all Chapter 9 institutions ('state institutions supporting constitutional democracy'), should consider delegating to the Electoral Commission more power over the running of elections, to enable it to infuse professionalism, efficiency and effectiveness into its operations.

From a public administration and management perspective, two dynamics can be said to underpin the management of the 2009 elections. Firstly, the elections were managed at two levels, the strategic and administrative. The strategic level, which is critical to planning, policy, and decision-making, involved strategic interventions to drive the election process forward. The administrative level is also very important as it determines the delivery of programmes and projects pertaining to the elections. Secondly, each of the two strands (strategic and administrative) had its own chain of processes, as outlined above, but the importance of meaningful collaboration with various stakeholders enhanced the success of the 2009 elections. 
Steytler, Murphy, De Vos \& Rwelamira (1994, p v) argue that ' $\mathrm{t}$ ] he value of the election will be determined by the extent to which it has been free and fair.' However, the extent to which elections are free and fair actually depends on the effective and efficient management and coordination of logistical and other functions. They further state ( $\mathrm{p}$ xviii) that '[p]olitical theorists suggest that the purpose of elections is to ensure either the orderly transfer of power from one group to another, or ... to legitimate its continued rule.' Notably, they add that the highest value of an election within the democratic discourse is that it legitimates power. However, it is the view of this author that the extent of freeness and fairness as well as the orderly transfer of such power ultimately rests on the shoulders of electoral officials and international best practice on elections management.

Admittedly, as Steytler, Murphy, De Vos \& Rwelamira (1994, pxxxi) argue, 'It may not be possible to have a totally free and fair election, what is necessary is that the election should be tolerably free and tolerably fair.' This might seem a matter of semantics but it does accommodate the possibility of human error, fatigue, erroneous counting, and so on, which have to be expected in the management of any election. The big question, of course, is how big such a margin of error or accommodation may be, but it is probably the electorate, various internal stakeholders and international observers who are best placed to answer this.

Finally, this article has deliberately avoided the political or merely ceremonial issues which often gain massive media coverage and has instead sought to underscore the significance of election management in order to highlight both the strategic and operational issues that relate to it. It has described the complexities of election management and argued that these complexities should neither be overlooked nor ignored as they play a crucial role in ensuring the freeness, fairness and credibility of elections. The article unpacked the management and logistical challenges, opportunities and dynamics of election management and outlined the relevant legislative framework, financial costs and challenges experienced by South Africans during Elections 2009. 


\section{- REFERENCES}

\section{Publications}

Ajulu, R. 2010. A Historical Overview of the South African Democratic Transition Since 1994. Johannesburg: EISA.

Balogun, M J. 2003. 'Election Monitoring: An Early Warning Perspective and Governance Capacity Building Strategy'. African Administrative Studies 61.

Baxter, J. 1994. 'Techniques to Effective Election Management'. Paper presented at the African Election Administration Colloquium, 15-18 November, Victoria Falls, Zimbabwe. Available at: aceproject.org/ero-en/topics/ electoralmanagement/techniques, Accessed 30/08/2009

Booysen, S \& G Masterson. 2009. 'South Africa'. In D Kadima \& S Booysen (eds). Compendium of Elections in Southern Africa 1989-2009: 20 Years of Multiparty Democracy. Johannesburg: EISA.

Deegan, H. 1999. South Africa Reborn. London: UCL Press.

EISA. 2009. 'South Africans line up in London to make their mark'. Regional Roundup. Available at: www.eisa.org.za.

February, J. 2010. 'The Electoral System and Electoral Administration'. In R Southall \& J Daniel (eds). Zunami! The 2009 South African Elections. Johannesburg: Jacana Media \& Konrad Adenauer Foundation.

Green, J C. 2006. 'Money and elections'. In S C Craig (ed). The Electoral Challenge: Theory Meets Practice. Washington, DC: CQ Press.

Human Sciences Research Council. 2009. IEC Voter and Election Observer Survey Report. Pretoria: HSRC.

IDEA. 2005. Electoral System Design: The New International IDEA Handbook. Stockholm: IDEA.

IEC. 1999. Report of the Electoral Commission of South Africa on the National and Provincial Elections, 2 June 1999. Pretoria: Electoral Commission.

- 2000. Electoral Commission Report on the Municipal Elections, 5 December 2000. Pretoria: Electoral Commission.

- 2003. 'Presentation at the Regional Workshop on Capacities Building in Electoral Administration in Africa'. African Administrative Studies 61.

- 2006. 2006 Municipal Elections Report. Pretoria: Electoral Commission.

- 2007. Multi-Stakeholder Conference: Reflections on Democracy in South Africa. Pretoria: Electoral Commission.

- 2009a. Elections 2009: To the Future. Information brochure. Pretoria: Electoral Commission.

- 2009b. IEC Election Guide 2009. Pretoria: Electoral Commission.

- 2009c. 'Final arrangements for voters who will be outside South Africa 
on Election Day'. Media release, 3 April. Available at: www.elections. org.za

- 2009d. 'IEC launches state of the art results operations centre'. Media release, 15 April. Available at: www.elections.org.za

—_. 2009e. 'Briefing of International Observers'. Media release, 17 April. Available at www.elections.org.za

_ 2009f. 'Tranquil and Harmonious Atmosphere as South Africans Cast Their Ballot, 22 Apr 2009'. Media release, 22 April. Available at: www. elections.org.za

- 2009g. 'IEC announces final results in South African poll'. Media release, 25 April. Available at: www.elections.org.za

_. 2009h. 2009 Elections Report. Pretoria: Electoral Commission.

Kimmie, Z, J M Greben \& S Booysen. 2010. 'The Effect of Changes in Registration and Turnout on the Results of the 2009 South African Election'. Politeia 29(1).

Lodge, T. 2002. Politics in South Africa: From Mandela to Mbeki. Cape Town: David Philip Publishers.

Massicotte, L, A Blais \& A Yoshinaka. 2004. Establishing the Rules of the Game: Election laws in Demarcates. Toronto: University of Toronto Press.

Murphy, J. 1994. 'An Independent Electoral Commission'. In N J Steytler, J Murphy, P de Vos \& M Rwelamira (eds). Free And Fair Elections. Cape Town: Juta and Co.

Oyugi, W O. 2003. 'The link between resources and the conduct of elections in Africa'. Paper delivered at the In Africa conference: Elections, Democracy and Governance, 7-17 April, Pretoria.

Schraeder, P J. 2003. African Politics and Society: A Mosaic in Transformation. Belmont: Wadsworth/Thomson.

Sebudubudu, D \& M Z Botlhomilwe. 2010. 'The Management of Elections: The case of Botswana'. Politeia 29(1).

Southall, R \& J Daniel (eds). 2010. Zunami! The 2009 South African Elections. Johannesburg: Jacana Media \& Konrad Adenauer Foundation.

Steytler, N, J Murphy, P de Vos \& M Rwelamira (eds). 1994. Free and Fair Elections. Cape Town: Juta \& Co.

Tlakula, P. 2006. Overview by the Chief Electoral Officer. Municipal Elections Report. Pretoria: Electoral Commission.

-_-_. 2008. Launch of Elections 2009, Address by Adv. Pansy Tlakula, Electoral Commission of South Africa Chief Electoral Officer, 17September 2008. Gallagher Convention Centre, Midrand.

UNDP. 2000. Electoral Management Bodies as Institutions of Governance. New York: United Nations Development Programme. 
UNDP Malawi. nd. Free and fair elections for Malawi: Support to electoral reforms and elections in Malawi'. Lilongwe: UNDP.

Van Niekerk, D, G van der Waldt \& A Jonker. 2001. Governance, Politics and Policy in South Africa. Cape Town: Oxford University Press.

Wikipedia. 2010. 'Absentee ballot'. Available at: en.wikipedia.org/

\section{Legislation}

Constitution of the Republic of South Africa, Act 108 of 1996. Pretoria: Government Printers.

Electoral Act, Act 73 of 1998 and Regulations. Cape Town: Juta \& Co.

Electoral Commission Act, Act 51 of 1996 and Regulations. Cape Town: Juta \& Co.

Local Government: Municipal Structures Act, Act 117 of 1998. Pretoria: Government Printers.

Public Finance Management Act, Act 1 of 1999. Pretoria: Government Printers. 